\title{
The feasibility of trace element supplementation for stable operation of wheat stillage-fed biogas tank reactors
}

\author{
Jenny Gustavsson, Bo Svensson and Anna Karlsson
}

\section{Linköping University Post Print}

N.B.: When citing this work, cite the original article.

CIWA Publishing 2011. The definitive peer-reviewed and edited version of this article is published in

Jenny Gustavsson, Bo Svensson and Anna Karlsson, The feasibility of trace element supplementation for stable operation of wheat stillage-fed biogas tank reactors, 2011, Water Science and Technology, (64), 2, 320-325.

http://dx.doi.org/10.2166/wst.2011.633

and is available at www.iwapublishing.com.

Postprint available at: Linköping University Electronic Press

http://urn.kb.se/resolve?urn=urn:nbn:se:liu:diva-70229 


\title{
The feasibility of trace element supplementation for stable operation of wheat stillage-fed biogas tank reactors
}

\author{
J. Gustavsson, B. H. Svensson and A. Karlsson
}

Department of thematic studies - Water and Environmental Studies, Linköping University, 58183

Linköping, Sweden (E-mail: jenny.gustavsson@liu.se; bosseh@tema.liu.se; anna.karlsson@liu.se)

\begin{abstract}
The aim of this study was to investigate the effect of trace element supplementation on operation of wheat stillage-fed biogas tank reactors. The stillage used was a residue from bio-ethanol production, containing high levels of sulfate. In biogas production, high sulfate content has been associated with poor process stability in terms of low methane production and accumulation of process intermediates. However, the results of the present study show that this problem can be overcome by trace element supplementation. Four lab-scale wheat stillage-fed biogas tank reactors were operated for 345 days at a hydraulic retention time of 20 days $\left(37^{\circ} \mathrm{C}\right)$. It was concluded that daily supplementation with $\mathrm{Co}\left(0.5 \mathrm{mg} \mathrm{L}^{-1}\right), \mathrm{Ni}\left(0.2 \mathrm{mg} \mathrm{L}^{-1}\right)$ and $\mathrm{Fe}\left(0.5 \mathrm{~g} \mathrm{~L}^{-1}\right)$ were required for maintaining process stability at the organic loading rate of $4.0 \mathrm{~g}$ volatile solids $\mathrm{L}^{-1}$ day $^{-1}$.
\end{abstract}

Keywords: biogas; sulfides; trace elements; wheat stillage

\section{INTRODUCTION}

Stillage is a by-product from ethanol distillation, which can be utilized for biogas production. The ethanol distillation process requires a hydrolysis step, for which sulfuric acid can be applied and therefore the resulting stillage will contain sulfate concentrations which may negatively affect the biogas process (Wilkie et al., 2000; Hutnan et al. 2003). This is because sulfate is a more favorable electron acceptor than $\mathrm{CO}_{2}$ resulting in less methane formed, why sulfate should ideally be minimized or eliminated before anaerobic digestion (AD). Thus, during $\mathrm{AD}$, sulfate is reduced to sulfide by sulfate-reducing bacteria, and these organisms compete with the methanogens for acetate and hydrogen (Koster et al., 1986; Hilton and Oleszkiewicz, 1988; Harada et al., 1994). In addition, inhibition by sulfide has been suggested to be a common reason for biogas process failure (Chen et al., 2007). High contents of sulfides may also be problematic due to precipitation and complexation of metals, with consequent reductions in the availability of trace metals for microorganisms. For instance, Barber and Stuckey (2000) proposed that sulfide precipitation reduces the bioavailability of $\mathrm{Fe}, \mathrm{Co}$ and $\mathrm{Ni}$ as nutrients in anaerobic biogas processes, and that the complexing potential increases with increased sulfide concentrations. This indicates that metal supplementation may improve processes with high sulfur levels. Following an investigation of the effects of $\mathrm{Fe}, \mathrm{Ni}, \mathrm{Zn}$ and $\mathrm{Co}$ on the total methanogenic and sulfidogenic activities in the anaerobic metabolization of sulfate-laden organics, Patidar and Tare (2006) found that metal supplementation (especially Fe and Co addition) stimulated methanogenic and sulfidogenic activities. Positive effects (i.e. increasing methane production rates and organic loading rates (OLRs), with concomitant reductions in levels of volatile fatty acids (VFAs)) of trace element addition has also been shown with a large number of other substrates (Murray and van den Berg, 1981; Wilkie et al., 1986; Takashima and Speece, 1989; Florencio et al.; 1993; Jarvis et al.; 1997; Kim et al., 2002). There have also been several reports of the effects of metal supplementation on biogas production from stillage (Espinosa et al., 1995; Wilkie et al., 2000; Hutnan et al., 2003; Alger et al., 2008). Notably, Alger et al. (2008) found that Co was 
required as a growth factor for cultures in corn stillage-fed thermophilic anaerobic sequencing batch reactors, at an OLR of $7.50 \mathrm{~g}$ total chemical oxygen demand (TCOD) $\mathrm{L}^{-1} \mathrm{day}^{-1}$. Espinosa et al. (1995) observed positive effects following addition of $\mathrm{Fe}, \mathrm{Co}, \mathrm{Ni}$ and Mo to a molasses stillage-fed UASB process, including significant reductions in levels of VFAs and increased gas production (OLR of $21.5 \mathrm{~g}$ chemical oxygen demand (COD) $\mathrm{L}^{-1} \mathrm{day}^{-1}$ ). Biogas production from stillage has also been studied by Wilkie et al. (2000), and Hutnan et al. (2003). The former reviewed stillage characterization, stillage treatment and by-product recovery in the ethanol industry, and concluded that high levels of potassium, metals and sulfate, and the presence of phenolic compounds, are all connected to stillage digestion deficiencies. They also presented observations regarding the performance of both mesophilic and thermophilic AD processes, in which several types of stillage were utilized. The mesophilic processes were operated at OLRs between 9-12 $\mathrm{g} \mathrm{COD} \mathrm{L}^{-1} \mathrm{day}^{-1}$. Similar results were obtained for the thermophilic processes regarding methane production and COD-reduction, but with twice the OLR as for the mesophilic systems (Wilkie et al., 2000). Hutnan et al. (2003) treated wheat stillage in one- and two-stage laboratory-scale reactors at an OLR of $12 \mathrm{~g} \mathrm{~L}^{-1} \mathrm{day}^{-1}$, but the sulfate level of this process was not known.

However, to the best of our knowledge there have been no published studies on the effects of trace element amendment to wheat stillage-fed biogas processes. Therefore, the aim of this study was to investigate the effects of such supplementation on processes in wheat stillage-fed biogas tank reactors, and the scope for using supplementation to stabilize their operation at an OLR of at least $2.5 \mathrm{~g}$ volatile solids (VS) $\mathrm{L}^{-1} \mathrm{day}^{-1}$ (approximately corresponding to $4 \mathrm{~g} \mathrm{COD} \mathrm{L}^{-1}$ day $\left.^{-1}\right)$.

\section{MATERIALS AND METHODS}

\section{Reactor startup and sampling}

Four 5-L glass bottles (designated J1-J4) with two openings at the top were used in the experiments. The contents were mixed at $400 \mathrm{rpm}^{*} 15 \mathrm{~min}^{-1} \mathrm{yy}^{-1}$ and both $10 \mathrm{~min}$ before and after sampling/feeding. For details regarding reactor design and daily maintenance, see Feng et al. (2010). The four reactors were operated at $37^{\circ} \mathrm{C}$ for 345 days with an HRT of 20 days. Inoculums were collected from a pilot-scale biogas plant and wheat stillage was obtained from Lantmännen Agroetanol AB, Norrköping, Sweden. The stillage was stored at $-20^{\circ} \mathrm{C}$ and thawed at room temperature before feeding. The total solids (TS) and VS content for the stillage was $16 \%$ and $95 \% \mathrm{TS}$ respectively, and for the inoculum it was $6 \%$ and $83 \% \mathrm{TS}$, respectively. Amongst other trace metals, the inoculum contained $12 \mathrm{mg} \mathrm{Co} \mathrm{kgTS}^{-1}$, $11 \mathrm{mg} \mathrm{Ni} \mathrm{kgTS}^{-1}$ and $10100 \mathrm{mg} \mathrm{Fe} \mathrm{kgTS}^{-1}$. The trace metal levels were generally much lower in the wheat stillage, which contained $0.56 \mathrm{mg} \mathrm{Co} \mathrm{kgTS}^{-1}, 0.63 \mathrm{mg} \mathrm{Ni} \mathrm{kgTS}{ }^{-1}$ and $180 \mathrm{mg} \mathrm{Fe} \mathrm{kgTS}^{-1}$. Moreover, the wheat stillage contained almost twice as high levels of sulfur as the inoculum (11500 and $5900 \mathrm{mg} \mathrm{kgTS}^{-1}$, respectively).

All four reactors were started at an OLR of $3.6 \mathrm{~g} \mathrm{VS} \mathrm{L}^{-1} \mathrm{day}^{-1}$, which was increased in two steps by $0.6 \mathrm{~g} \mathrm{VS} \mathrm{L}^{-1} \mathrm{day}^{-1}$, reaching $4.8 \mathrm{~g} \mathrm{VS} \mathrm{L}^{-1} \mathrm{day}^{-1}$ at day 7 . The OLR was decreased to $2.7 \mathrm{~g} \mathrm{VS} \mathrm{L}^{-1}$ day $^{-1}$ at day 50 , due to accumulation of VFAs and a decrease in $\mathrm{pH}$. From day 57 to 114 , an OLR of 1.0-1.5 $\mathrm{g} \mathrm{VS} \mathrm{L}^{-1} \mathrm{day}^{-1}$ was applied, after which it was increased, in intervals of $0.5 \mathrm{~g} \mathrm{VS} \mathrm{L}^{-1} \mathrm{day}^{-1}$, reaching $2.5 \mathrm{~g} \mathrm{VS} \mathrm{L}^{-1} \mathrm{day}^{-1}$ at day 120 . However, due to increasing VFA levels, the OLR once again was reduced to $1.5 \mathrm{~g} \mathrm{VS} \mathrm{L}^{-1} \mathrm{day}^{-1}$ at day 139. After a second process recovery, the OLR was increased (starting at day 160), as above, reaching $2.5 \mathrm{~g} \mathrm{VS} \mathrm{L}^{-1}$ day $^{-1}$ at day 167 . This OLR was then kept constant for reactors J1 and J2, while 
for J3 and J4 the OLR was further increased in intervals of $0.5 \mathrm{~g} \mathrm{VS} \mathrm{L}^{-1} \mathrm{day}^{-1}$ from day 265, reaching a final value of $4.0 \mathrm{~g} \mathrm{VS} \mathrm{L}^{-1} \mathrm{day}^{-1}$ at day 278 , which was sustained until the end of the experiment (day 345).

Supplementation of $\mathrm{Fe}$ (from a stock solution of $\mathrm{FeCl}_{2}$ ) was applied to precipitate sulfide, starting with a single dose of $0.8 \mathrm{~g} \mathrm{~L}^{-1}$ stillage on day 11 , followed by a daily addition of $0.5 \mathrm{~g} \mathrm{~L}^{-1}$ thereafter (with the exception of day 146-195 where it was $1.0 \mathrm{~g} \mathrm{~L}^{-1}$ ). Co amendment (from a stock solution of $\mathrm{CoCl}_{2} * 6 \mathrm{H}_{2} \mathrm{O}$ ) started at day 80, with daily feedings of $0.1 \mathrm{mg} \mathrm{L}^{-1} \mathrm{day}^{-1}$, and was increased to $0.5 \mathrm{mg} \mathrm{L}^{-1}$ day $^{-1}$ from day 146 . Ni supplement (from a stock solution of $\mathrm{NiCl}_{2} * 6 \mathrm{H}_{2} \mathrm{O}$ ) commenced from day 140 at $0.04 \mathrm{mg} \mathrm{L}^{-1} \mathrm{day}^{-1}$, increasing at day 146 to $0.2 \mathrm{mg} \mathrm{L}^{-1} \mathrm{day}^{-1}$. Between days 146 and 194, Se and $\mathrm{W}$ (from stock solutions of $\mathrm{Na}_{2} \mathrm{SeO}_{3} * 5 \mathrm{H}_{2} \mathrm{O}$ and $\mathrm{Na}_{2} \mathrm{WO}_{4} * 2 \mathrm{H}_{2} \mathrm{O}$ ) were added at 0.05 and $0.1 \mathrm{mg} \mathrm{L}^{-1}$ day ${ }^{-1}$, respectively. The trace element amendment over time is summarized in Table 1. Moreover, single doses of $\mathrm{CaCO}_{3}(\mathrm{~s})$ were added at days 89 and 103 in order to increase $\mathrm{pH}(2-15 \mathrm{~g} /$ reactor).

Table 1. Daily trace element supplementation of $\mathrm{Fe}, \mathrm{Co}, \mathrm{Ni}, \mathrm{Se}$ and $\mathrm{W}$ to reactors J1-J4.

\begin{tabular}{llllll}
\hline Days & $\begin{array}{l}\mathrm{Fe} \\
\left(\mathrm{g} \mathrm{L}^{-1}\right)\end{array}$ & $\begin{array}{l}\mathrm{Co} \\
\left(\mathrm{mg} \mathrm{L}^{-1}\right)\end{array}$ & $\begin{array}{l}\mathrm{Ni} \\
\left(\mathrm{mg} \mathrm{L}^{-1}\right)\end{array}$ & $\begin{array}{l}\mathrm{Se} \\
\left(\mathrm{mg} \mathrm{L}^{-1}\right)\end{array}$ & $\begin{array}{l}\mathrm{W} \\
\left(\mathrm{mg} \mathrm{L}^{-1}\right)\end{array}$ \\
\hline $1-10$ & 0 & 0 & 0 & 0 & 0 \\
11 & 0.8 & 0 & 0 & 0 & 0 \\
$12-79$ & 0.5 & 0 & 0 & 0 & 0 \\
$80-139$ & 0.5 & 0.1 & 0 & 0 & 0 \\
$140-145$ & 0.5 & 0.1 & 0.04 & 0 & 0 \\
$146-194$ & 1.0 & 0.5 & 0.2 & 0.05 & 0.1 \\
$195-345$ & 0.5 & 0.5 & 0.2 & 0 & 0 \\
\hline
\end{tabular}

\section{Evaluation of biogas process performance}

The biogas process performance was evaluated by measuring the total gas and methane production, the content of hydrogen sulfide in the gas, $\mathrm{pH}$, VFA concentrations and VSreduction. The total gas production was determined using gas meters, working on the basis of water displacement, and the methane production was measured once a week using a GFM 165400 Gas Analyser (Gas Data Ltd, Whitley, UK). The hydrogen sulfide content of the gas phase was determined using Dräger tubes for short-term hydrogen sulfide measurements (Accuro Gas Detection Pump, Dräger Safety Sweden AB). The $\mathrm{pH}$ was measured by a PHM93 meter (Radiometer, Copenhagen, 166 Denmark) and VFA concentrations (acetate, propionate, butyrate, iso-butyrate, valeriate, iso-valeriate, capronate and iso-capronate) were analyzed by gas chromatography with flame ionization detection (Jonsson \& Borén, 2002). The VS- reduction was determined by measuring the TS and VS (Swedish Standard SS$028113 ; 25)$. Sludge samples were collected once a month and stored at $-20^{\circ} \mathrm{C}$ for trace element analysis. These analyzes were performed by Eurofins Environment Sweden AB (Lidköping, Sweden) according to the Swedish standard method for determination of trace elements in soil (SS-028311), and also included total $\mathrm{N}$ (Kjeldahl) and ammonium-N measurements.

\section{RESULTS AND DISCUSSION}

The performance of the four reactors in terms of methane production rates, VFA concentrations and $\mathrm{pH}$ is illustrated in Figs. 1-3. A more or less immediate increase in VFA 
(mainly acetate) led to reductions in $\mathrm{pH}$ and methane formation rates at around day 50 . To abate this process decline, the OLR was decreased from 4.8 to $2.7 \mathrm{~g} \mathrm{VS} \mathrm{L}^{-1} \mathrm{day}^{-1}$ on day 50 and further to $1.0 \mathrm{~g} \mathrm{VS} \mathrm{L}^{-1} \mathrm{day}^{-1}$ on day 56. Co was added from day 80 (Table 1). However, the reactor performance continued to decline, thus, on day 100 , the $\mathrm{pH}$ was at $6.0-6.4$ and methane production had decreased from the initial ca. 400 to 30 $100 \mathrm{~mL}$ methane $\mathrm{g} \mathrm{VS}_{\mathrm{in}}{ }^{-1} \mathrm{day}^{-1}$ (Fig. 1). $\mathrm{CaCO}_{3}$ (s) was added in order to increase the $\mathrm{pH}$, but the processes did not respond to this treatment. To prevent total process failure, half of the reactor liquid volumes were exchanged for new material from the pilot plant on day 103 . The processes immediately recovered with respect to $\mathrm{pH}$, VFA concentrations and methane production. Fe $\left(0.5 \mathrm{~g} \mathrm{~L}^{-1} \mathrm{day}^{-1}\right)$ and $\mathrm{Co}\left(0.1 \mathrm{mg} \mathrm{L}^{-1} \mathrm{day}^{-1}\right)$ supplementation continued and at day 120 the OLR was increased to $2.5 \mathrm{~g} \mathrm{VS} \mathrm{L}^{-1}$ day $^{-1}$.

On day 138, however, the $\mathrm{pH}$ started to drop again in two of the reactors (J1 and J2). The OLR was then decreased to $1.5 \mathrm{~g} \mathrm{VS} \mathrm{L}^{-1} \mathrm{day}^{-1}$ in all four reactors and $\mathrm{Ni}$ supplement was started at day $140\left(0.04 \mathrm{mg} \mathrm{L}^{-1} \mathrm{day}^{-1}\right.$; Table 1$)$. The processes did not respond to the measures applied and $\mathrm{pH}$ continued to drop, in reactor $\mathrm{J} 4$ as well as in $\mathrm{J} 1$ and $\mathrm{J} 2$. On day 146 metal dosing was increased, by doubling Fe addition, and increasing Co and Ni amendment fivefold. Se and W supplement was also started (Table 1). These treatments resulted in decreased VFA concentrations, increased $\mathrm{pH}$ and stabilized methane production within a week. After another week (day 160), the processes were recovered, i.e. average $\mathrm{pH}$ rose to ca. 7.5 , there were no detectable VFAs and methane production averaged $460 \mathrm{~mL}$ methane $\mathrm{g} \mathrm{VS}_{\mathrm{in}}{ }^{-1} \mathrm{day}^{-1}$ in the four reactors (Figs. 1-3). The OLR was then increased again, reaching $2.5 \mathrm{~g} \mathrm{VS} \mathrm{L}^{-1} \mathrm{day}^{-1}$ at day 167. At day 195 the $\mathrm{Fe}$ addition was decreased to $0.5 \mathrm{~g} \mathrm{~L}^{-1}$ day $^{-1}$ and the Se and $\mathrm{W}$ addition was terminated. The processes remained stable for more than three HRTs after these changes. During the period of stable operation (from day 160), the $\mathrm{pH}$ varied between 7.4 and 7.8, VFA concentrations were below detection limits and the weekly average methane production was $410 \mathrm{~mL}$ methane $\mathrm{g} \mathrm{VS}_{\mathrm{in}}{ }^{-1} \mathrm{day}^{-1}$, with a relative standard deviation of $11 \%$ for the four reactors. From day 265 the OLR was increased in reactors J3 and J4, reaching $4.0 \mathrm{~g} \mathrm{VS} \mathrm{L}^{-1} \mathrm{day}^{-1}$ on day 278 . At day 345 , process conditions in all reactors were still stable (Figs. 1-3), but the $\mathrm{pH}$ was 7.5 in reactors $\mathrm{J} 1$ and J2, while at 7.8 in J3 and J4 (Fig. 3).

The VS-reduction amounted to $60-70 \%$ from days 1 to 50 (data not shown), and thereafter varied between $10-60 \%$ due to the instability of the process. Under stable conditions (from day 160 onwards) the VS-reduction was around $70 \%$ in all reactors. The amount of hydrogen sulfide in the gas was considerably higher when the processes were operated at $4.0 \mathrm{~g} \mathrm{VS} \mathrm{L}^{-1}$ day $^{-1}(0.4-0.5 \%)$ than when they were operated at $2.5 \mathrm{~g} \mathrm{VS} \mathrm{L}^{-1}$ day $^{-1}(0.2 \%)$. On two occasions the $\mathrm{pH}$ dropped and VFAs (mainly acetic acid) accumulated, indicating an imbalance in the conversion rates of the biogas processes. On the first occasion, half of the reactor material was exchanged with new material from the pilot plant. This material contained higher levels of $\mathrm{Co}$ and $\mathrm{Ni}$ than the experimental reactor material and the substrate. As only Fe was added to the reactors at the beginning of the experiment (day 11), the levels of $\mathrm{Co}$ and $\mathrm{Ni}$ decreased over time in the reactor material (data not shown). All reactors immediately recovered after the $\mathrm{Co}$ and $\mathrm{Ni}$ addition; hence the instability was likely caused by $\mathrm{Co}$ and $\mathrm{Ni}$ washout. On the second occasion of instability, indicated by a $\mathrm{pH}$ decrease and an increase in VFA, a five-fold increase in $\mathrm{Co}$ and $\mathrm{Ni}$ supplement was introduced, together with $\mathrm{Se}$ and $\mathrm{W}$ addition. This treatment resulted in full recovery of the process within two weeks, and it was concluded that the process instability was connected to poor availability of trace elements. The removal of Se and $\mathrm{W}$ did not have any effects on the processes, since they continued to be stable until termination (after more than three HRTs). Accordingly, Se and W 
supplementation was not necessary at ORLs of up to $4.0 \mathrm{~g} \mathrm{VS} \mathrm{L}^{-1} \mathrm{day}^{-1}$. These findings show that the cause of process instability was linked to poor availability of Co and/or Ni.

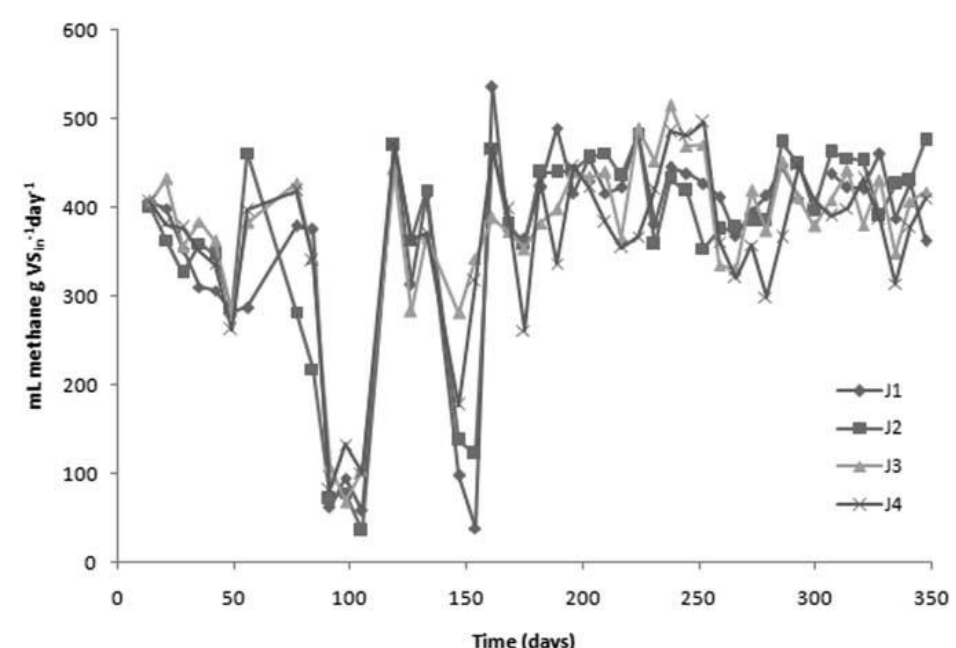

Figure 1 Methane production $\left(\mathrm{mL}\right.$ methane $\left.\mathrm{g} \mathrm{VS}_{\mathrm{in}}{ }^{-1} \mathrm{day}^{-1}\right)$ in reactors $\mathrm{J} 1-\mathrm{J} 4$ from day 1 to day 348 .

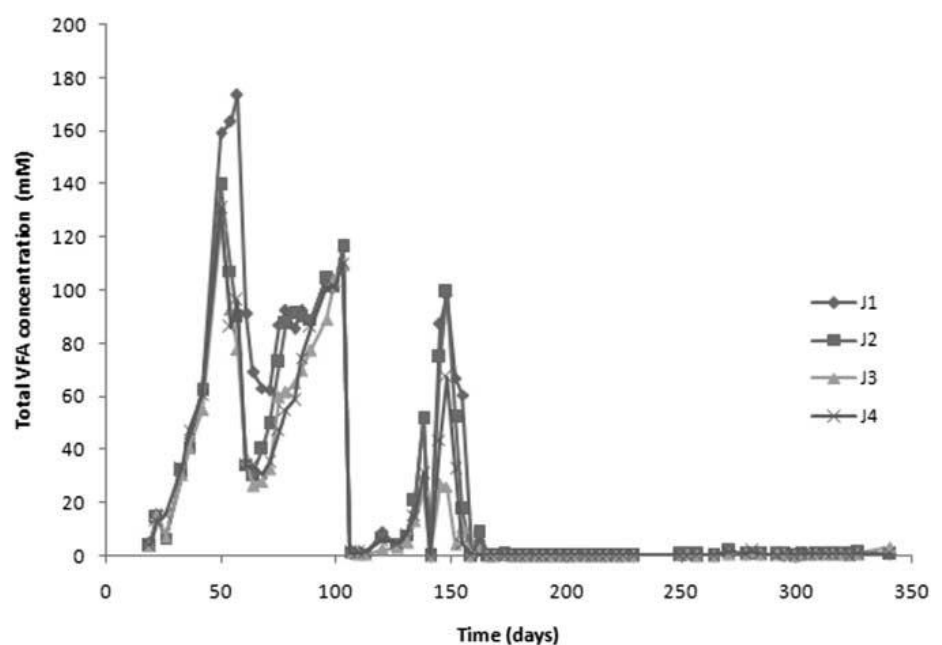

Figure. 2 Concentration of total VFA (mM) in reactors J1-J4 from day 1 to day 345.

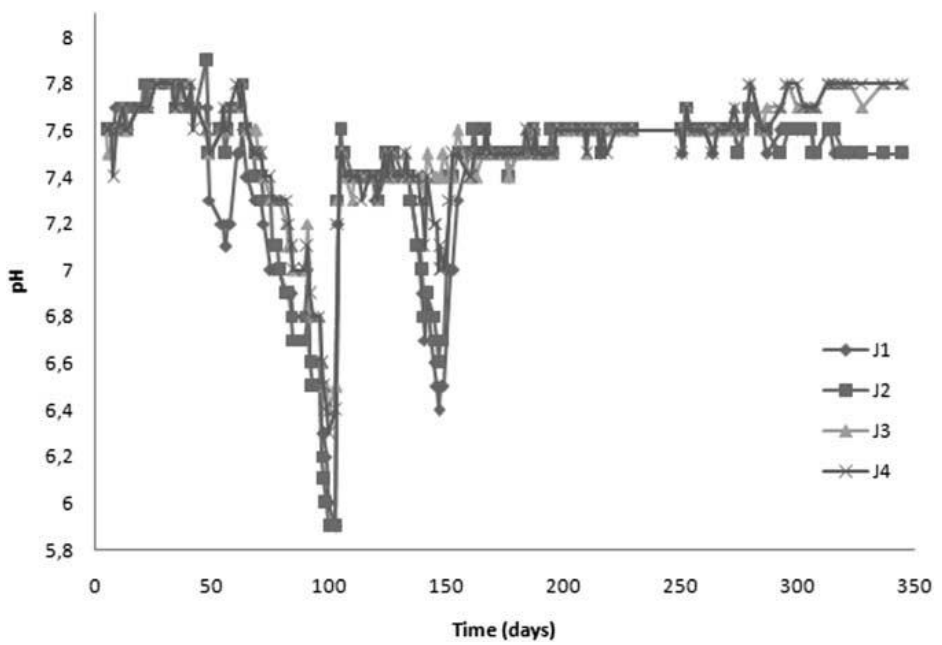

Figure. $3 \mathrm{pH}$ in reactors J1-J4 from day 0 to day 345. 
In accordance with results from previous studies (Barber and Stuckey, 2000; Gonzalez-Gil et al., 2003; Patidar and Tare, 2006), this was likely connected to the high sulfide content in the reactors and metal-sulfide interactions. However, this has to be further investigated to be definitively established. Clearly, there were critical limits for the amount of $\mathrm{Co}$ and $\mathrm{Ni}$ supplementation. $0.1 \mathrm{mg} \mathrm{Co} \mathrm{L}^{-1}$ day $^{-1}$ and $0.04 \mathrm{mg} \mathrm{Ni} \mathrm{L}^{-1} \mathrm{day}^{-1}$ were not sufficient for stable process operation, even at an OLR of $1.0 \mathrm{~g} \mathrm{VS} \mathrm{L}^{-1} \mathrm{day}^{-1}$. Whether only one or both of the trace metals were responsible for the stabilization of the processes cannot be concluded from this study.

During stable operation (from day 160 to 345), the methane production in all four reactors was about $400 \mathrm{~mL}$ methane $\mathrm{g} \mathrm{VS}_{\text {in }}{ }^{-1} \mathrm{day}^{-1}$ (equivalent to $250 \mathrm{~mL}$ methane $\mathrm{g}^{-1}$ total $\mathrm{COD}_{\text {in }}{ }^{-1}$ ) and the VS-reduction was about $70 \%$ at the OLR of $2.5-4.0 \mathrm{~g} \mathrm{VS} \mathrm{L}^{-1} \mathrm{day}^{-1}$ (equivalent to 4-6.4 $\mathrm{g} \mathrm{COD} \mathrm{L}^{-1} \mathrm{day}^{-1}$ ). These results are in accordance with previous reports for methane production from stillage (Hutnan et al. (2003); $230 \mathrm{~mL} \mathrm{~g}^{-1}$ total $\mathrm{COD}_{\text {in }}{ }^{-1}$; Alger et al. (2008); $250 \mathrm{~mL} \mathrm{~g}^{-1}$ total $\mathrm{COD}_{\text {in }}{ }^{-1}$ ) and COD reduction $(70 \%$ for mesophilic processes; reviewed by Wilkie et al. 2000). The OLR applied in previous studies (7.5-21.5 g COD L day ${ }^{-1}$; Wilkie et al., 2000; Hutnan et al., 2003; Alger et al., 2008), can not be compared to what was obtained in this study since the substrate and process characteristics (including sulfur levels) differs considerably. Moreover, higher OLR than $4.0 \mathrm{~g} \mathrm{VS} \mathrm{L}^{-1} \mathrm{day}^{-1}$ was not tried out in our study.

\section{CONCLUSIONS}

Evidently, it was essential to augment the mesophilic wheat stillage-fed biogas tank reactors with $\mathrm{Co}$ and $\mathrm{Ni}$ for continuous stable process operation. To the best of our knowledge this is the first time that this has been clearly demonstrated. The sulfur concentration of the wheat stillage used in this study was $11500 \mathrm{mg} \mathrm{S} \mathrm{kgTS}^{-1}$, due to the sulfuric acid use during the ethanol fermentation. The high sulfide content may have affected the availability of Co and $\mathrm{Ni}$, and thus the addition of these trace elements improved the process conditions. The interactions between the sulfides and the trace elements are presently further investigated in our laboratory. The optimum supplementation amounts for biogas production were not established in this study, but it was concluded that $0.5 \mathrm{~g} \mathrm{Fe} \mathrm{L}^{-1} \mathrm{day}^{-1}, 0.5 \mathrm{mg} \mathrm{Co} \mathrm{L}^{-1} \mathrm{day}^{-1}$ and $0.2 \mathrm{mg} \mathrm{Ni}^{-1} \mathrm{day}^{-1}$ were sufficient for stable process operation at OLRs up to $4.0 \mathrm{~g} \mathrm{VS} \mathrm{L}^{-1} \mathrm{day}^{-1}$. Moreover, supplementation of $0.1 \mathrm{mg} \mathrm{Co} \mathrm{L}^{-1} \mathrm{day}^{-1}$ and $0.04 \mathrm{mg} \mathrm{Ni} \mathrm{L}^{-1}$ day $^{-1}$ was evidently too low for the present processes.

\section{ACKNOWLEDGEMENT}

The authors thank Jörgen Ejlertsson for useful help in preparing this study, and the weekend feeding team for assistance in the laboratory. We also thank Agroetanol AB for providing stillage for the experiments. This study was supported by the Swedish Energy Agency.

\section{REFERENCES}

Alger M., Garcia M., Lee E, Schlicher M, and Angenent L. (2008). Thermophilic anaerobic digestion to increase the net energy balance of corn grain ethanol. Environ. Sci. Technol, 42, $6723-6729$. 
Barber W. P., and Stuckey D. C. (2000). Metal bioavailability and trivalent chromium removal in ABR. .J. Environ. Eng., 126(7), 649-656.

Chen Y., Cheng J. J., and Creamer K. S. (2007). Inhibition of anaerobic digestion process: A review. Biores. Technol., 99(10), 4044-4064.

Espinosa A., Rosas L., Ilangovan K., and Noyola A. (1995). Effect of trace metals on the anaerobic degradation of volatile fatty acids in molasses stillage. Wat. Sci. Tech., 32(12), 121129.

Feng X. M., Karlsson A., Svensson B. H., and Bertilsson S. (2010). Impact of trace element addition on biogas production from food industrial waste - linking process to microflora. FEMS Microbiol. Ecol., 74(1), 226-240.

Florencio L., Jenicek P., Field J. A., and Lettinga G. (1993). Effect of cobalt on the anaerobic degradation of methanol. J. Ferment. Bioeng., 75(5), 386-374.

Jarvis A., Nordberg A., Jarlsvik T., Mathisen B., and Svensson B. H. (1997). Improvement of a grass-clover silage-fed biogas process by the addition of cobalt. Biomass Bioenergy, 12(6), 453-460.

Gonzalez-Gil G., Jansen S., Zandvoort M. H., and van Leeuwen H. P. (2003). Effect of yeast extract on speciation and bioavailability of nickel and cobalt in anaerobic bioreactors. Biotechnol. Bioeng., 82(2), 134-142.

Harada H., Uemura S., and Monomoi K. (1994). Interactions between sulphate-reducing bacteria and methane-producing bacteria in UASB reactors fed with low strength wastes containing different levels of sulphate. Water Res., 28(2), 355-367.

Hilton B. L., and Oleszkiewicz J. A. (1988). Sulphide-induced inhibition of anaerobic digestion. J. Environ. Eng., 114, 1377-1391.

Hutnan M., Hornak M., Bodík I., and Hlavacka V. (2003). Anaerobic treatment of wheat stillage. Chem. Biochem. Eng. Q., 17(3), 233-241.

Jonsson S., and Borén H. (2002). Analysis of mono- and diesters of o-phthalic acid by solid phase extractions with polystyrene-divinylbenzene-based polymers. J. Chromatogr. A, 963, 393-400.

Kim M., Ahn Y. H. and Speece R. E. (2002). Comparative process stability and efficiency of anaerobic digestion; mesophilic vs. thermophilic. Water Res., 36(17), 4369-4385.

Koster I. W., Rinzema A., De Vegt A. L., and Lettinga G. (1986). Sulfide inhibition of the methanogenic activity of granular sludge at various pH levels. Water Res., 20, 1561-1567.

Murray W. D., and van den Berg L. (1981). Effects of nickel, cobalt, and molybdenum on performance of methanogenic fixed-film reactors. Appl. Environ. Microbiol., 42(3), 502-505.

Patidar S. K., and Tare V. (2006). Effect of nutrients on biomass activity in degradation of sulfate laden organics. Process Biochem., 41, 489-495 
Takashima M., and Speece R. E. (1989). Mineral nutrient requirements for high-rate methane fermentation of acetate at low SRT. Res. J. Wat. Poll. Cont. Fed., 61(11-12), 1645-1650.

Wilkie A. C., Goto M., Bordeaux F. M., and Smith P. H. (1986). Enhancement of anaerobic methanogenesis from napiergrass by addition of micronutrients. Biomass London, 11(2), 135146.

Wilkie A. C., Riedesel K. J., and Owens J. M. (2000). Stillage characterization and anaerobic treatment of ethanol stillage from conventional and cellulosic feedstock. Biomass Bioenergy, $19(2)$ 63-102. 